\title{
Glycemic control affecting the autonomic modulation in type 2 diabetes
}

\author{
Daniela Bassi, , Vivian Maria Arakelian, Renata Gonçalves Mendes, Flávia Cristina Rossi Caruso, \\ Luis Carlos Bonjorno Júnior, Ross Arena, Audrey Borghi e Silva \\ From 20th Brazilian Diabetes Society Congress \\ Porto Alegre, Brazil. 11-18 November 2015
}

\section{Background}

Diabetes Mellitus (DM) is a chronic disease with high morbidity and mortality and one of the most important risk factors for developing cardiovascular disease. DM is associated with cardiac autonomic dysfunction.

\section{Objective}

To evaluate if the glycemic control affects cardiac autonomic modulation in individuals with type 2 diabetes.

\section{Materials and methods}

We evaluated 49 patients $(51.2 \pm 7.7$ yrs.) with a confirmed diagnosis of diabetes. The subjects were randomized in two groups according to glycated hemoglobin-HbA1c: $\mathrm{HbA} 1 \mathrm{c}<7 \%$ and $\mathrm{HbA} 1 \mathrm{c}>7 \%$. The fasting plasma glucose and $\mathrm{HbA} 1 \mathrm{c}$ were performed in a specialized laboratory and $H R$ and $i R R$ were recorded for $10 \mathrm{~min}$ in the supine position. Statistical analysis included Shapiro-Wilk Test, Mann Whitney Test and Spearman Correlation.

\section{Results}

Diabetics with $\mathrm{HbA} 1 \mathrm{c}>7$ presented lower values of all HRV indices compared to diabetics with $\mathrm{HbA1c}<7$ (mean $\mathrm{iRR}=844.25 \pm 117.64$ vs $928.47 \pm 67.83 \mathrm{~ms}$; STDRR $=21.13$ \pm 12.85 vs $34.92 \pm 19.51 \mathrm{~ms}$; RR Tri $=5.57 \pm 3.07$ vs $9.02 \pm 5.12$; $\mathrm{TINN}=107.82 \pm 65.72$ vs $149 \pm 50.32, \mathrm{SD} 2=37.70 \pm 19.11$ vs $61.94 \pm 25.06 \mathrm{~ms}$, except for mean HR $(72.45 \pm 9.55$ vs 65.12 $\pm 4.91 \mathrm{bpm})$ where was higher in HbA1c $>7$ group. HbA1c was negatively correlated with mean iRR $(\mathrm{r}=-0.28)$; STDRR $(\mathrm{r}=-0.33)$; RRTri $(\mathrm{r}=-0.35)$, SD2 $(\mathrm{r}=-0.39)$ and positively with mean $\mathrm{HR}(\mathrm{r}=0.28)$. Whereas fasting plasma glucose was negatively correlated with SD2 $(\mathrm{r}=-0.42)$; STDRR $(\mathrm{r}=-0.36)$, RRTri $(\mathrm{r}=-0.36)$ and TINN $(\mathrm{r}=0.33)$.

\footnotetext{
* Correspondence: danibassi26@ig.com.br

Universidade Federal de São Carlos, São Carlos, Brazil

\section{Conclusion}

These findings suggest attenuated cardiac autonomic response in diabetics type 2 with poor metabolic control.

Published: 11 November 2015

doi:10.1186/1758-5996-7-S1-A3

Cite this article as: Bassi et al:: Glycemic control affecting the autonomic modulation in type 2 diabetes. Diabetology \& Metabolic Syndrome 20157 (Suppl 1):A3.
Submit your next manuscript to BioMed Central and take full advantage of:

- Convenient online submission

- Thorough peer review

- No space constraints or color figure charges

- Immediate publication on acceptance

- Inclusion in PubMed, CAS, Scopus and Google Scholar

- Research which is freely available for redistribution

Submit your manuscript at www.biomedcentral.com/submit
() Biomed Central 